\title{
Penerapan Token Economy dalam Meningkatkan Active Learning Anak Usia Dini
}

\author{
Elizabeth Prima ${ }^{1 凶}$, Putu Indah Lestari $^{2}$ \\ Pendidikan Guru Pendidikan Anak Usia Dini, Universitas Dhyana Pura \\ DOI: $10.31004 /$ obsesi.v5i2.829
}

\begin{abstract}
Abstrak
Penelitian ini bertujuan untuk meningkatan active learning pada anak usia dini melalui penerapan teknik token economy. Jenis penelitian ini adalah Quasi Experimental Design dengan rancangan nonequivalent control group design. Pada penelitian ini penentuan kelompok kontrol dan kelompok eksperimen dilakukan secara acak terhadap kelas yang ada. Ada dua kelompok yaitu kelompok eksperimen dan kelompok kontrol, satu mendapatkan perlakuan dan satu kelompok kontrol, keduanya memperoleh pre-test dan post-test. Dari hasil uji-t untuk kelas eksperimen diperoleh $t_{\text {hitung }}=13,077$ dan taraf signifikan $5 \%$ dengan derajat kebebasan 38 diperoleh $t_{\text {tabel }}=2,538$. Dengan membandingkan hasil $t_{\text {hitung }}$ dan $t_{\text {tabel }}$ dapat disimpulkan bahwa $t_{\text {hitung }}>t_{\text {tabel }}(13,077>2,538)$, maka $\mathrm{H}_{1}$ diterima dan $\mathrm{H}_{\mathrm{o}}$ ditolak. Berdasarkan hasil perhitungan uji-t menunjukkan bahwa terdapat perbedaan yang signifikan antara kelompok yang dibelajarkan dengan penerapan teknik token economy dengan anak yang dibelajarkan dengan pembelajaran konvensional pada anak usia dini. Sehingga dapat disimpulkan bahwa penerapan token economy dapat meningkatkan active learning pada anak usia dini.
\end{abstract}

Kata Kunci: active learning, token economy, anak usia dini.

\begin{abstract}
This study aims to increase active learning at an early age through the application of token economy technique. This type of research is a Quasi Experimental Design with a nonequivalent control group design. In this study, the control group and the experimental group were determined randomly to the existing class. There are two groups, namely the experimental group and the control group, one receiving treatment and one controlling the group, both receiving the pre- and post- test. From the result of the t-test for the experimental class, it is obtained $t_{\text {count }}=13,077$ and a significant level of $5 \%$ with 38 degrees of freedom obtained $t_{\text {table }}=2,835$. By comparing the results of $t_{\text {count }}$ and $t_{\text {table }}$ it can be concluded that $t_{\text {count }}>$ $t_{\text {table }}(13,077>2,835)$, so $H_{1}$ is accepted and $H_{0}$ is rejected. Based on the result of the calculation of $\mathrm{T}$ test, it shows that there is a significant difference between the groups that were taught using the token economy technique and those taught by conventional learning in early childhood. Therefore the conclusion is the application of token economy can increase active learning in early childhood.
\end{abstract}

Keywords: active learning, token economy, early childhood.

Copyright (c) 2020 Elizabeth Prima, Putu Indah Lestari

$\triangle$ Corresponding author :

Email Address : elizabethprima@undhirabali.ac.id (Denpasar, Bali)

Received 21 October 2020, Accepted 21 October 2020, Published 2 November 2020 


\section{PENDAHULUAN}

Setiap anak adalah individu yang berbeda satu sama lain, memiliki keunikan masingmasing yang tidak sama dengan orang lain. Oleh karena itu pembelajaran hendaknya memperhatikan perbedaan-perbedaan individual anak tersebut, sehingga pembelajaran benar-benar dapat merubah kondisi anak dari yang tidak tahu menjadi tahu, dari yang tidak paham menjadi paham serta dari yang berperilaku kurang baik menjadi baik. Sebagian guru cenderung memperhatikan kelas secara keseluruhan, bukan perorangan atau kelompok anak, sehingga perbedaan individual kurang mendapat perhatian. Gejala yang lain terlihat pada kenyataan banyaknya guru yang menggunakan metode pengajaran yang cenderung sama setiap kali pertemuan di kelas berlangsung. Bahkan guru hanya menggunakan buku teks dalam proses pembelajaran (Panjaitan et al., 2020).

Pembelajaran bagi anak usia dini adalah pembelajaran yang berorientasi belajar sambil bermain dan bermain sambil belajar dengan pendekatan yang berpusat pada anak. Pembelajaran juga merujuk pada pencapaian perkembangan anak sesuai dengan kelompok usia anak (Zamzami, 2021). Pembelajaran active learning dapat menjadi salah satu cara untuk mengoptimalkan penggunaan semua potensi yang dimiliki oleh anak, sehingga dapat mencapai hasil belajar yang maksimal. Pembelajaran aktif atau yang biasa disebut active learning adalah segala bentuk pembelajaran yang memungkinkan peserta didik berperan secara aktif dalam pembelajaran, baik dalam bentuk interaksi antar peserta didik ataupun peserta didik dengan guru dalam proses pembelajaran (Hamruni, 2012). Pembelajaran aktif ini diambil dari asumsi bahwa belajar pada dasarnya adalah proses yang aktif, dan orang yang berbeda, belajar dalam cara yang berbeda pula (Wina, 2016). Oleh karena itu sangat diharapkan dalam pembelajaran aktif, anak dapat terlibat aktif secara mental (intelektual dan emosional) maupun secara fisik. baik dilakukan guru atau siswa. Dengan demikian dalam strategi pembelajaran aktif terlihat guru aktif mengajar di satu pihak dan siswa aktif belajar di lain pihak. Konsep ini bersumber dari teori kurikulum yang berpusat pada anak (Solihatin, 2011).

Konsep active learning atau cara belajar siswa aktif, dapat diartikan sebagai panutan pembelajaran yang mengarah pada pengoptimalisasian pelibatan intelektual dan emosional siswa dalam proses pembelajaran, diarahkan untuk membelajarkan siswa bagaimana belajar memperoleh dan memproses perolehan belajarnya tentang pengetahuan, keterampilan, sikap dan nilai (Dimyati \& Mudjiono, 2013). Senada dengan definisi ini Hasanah (2019) mendefinisikan Pembelajaran aktif adalah kegiatan-kegiatan pembelajaran yang melibatkan para pelajar dalam melakukan suatu hal dan memikirkan apa yang sedang mereka lakukan.

Melalui pendekatan belajar aktif, anak diharapkan mampu mengenal dan mengembangkan kapasitas belajar dan potensi yang mereka miliki. Di samping itu, anak secara penuh dan sadar dapat menggunakan potensi sumber belajar yang terdapat di lingkungan sekitarnya, lebih terlatih untuk berprakarsa, berpikir secara sistematis, krisis dan tanggap, sehingga dapat menyelesaikan masalah sehari-hari melalui penelusuran informasi yang bermakna baginya.

Ada beberapa faktor yang mempengaruhi aktivitas belajar siswa antara lain Soemanto, 2012) menyebutkan faktor internal dan faktor eksternal. Faktor internal meliputi: a. Kematangan. Kematangan memberikan kondisi dimana fungsi-fungsi fisiologis termasuk sistem saraf, dan fungsi otak menjadi berkembang. Dengan berkembangnya fungsi-fungsi otak dan sistem saraf, akan menumbuhkan kapasitas mental seseorang dan mempengaruhi aktivitas belajar siswa. b. Pengalaman sebelumnya. Pengalaman yang diperoleh individu ikut mempengaruhi aktivitas belajar siswa, terutama dalam transfer belajarnya. c. Kesehatan jasmani dan rohani. Aktivitas belajar akan menjadi lebih baik jika siswa memiliki kondisi tubuh yang sehat dan dalam kondisi rohani yang juga sehat. 2) Faktor eksternal, yang meliputi: a. Bahan ajar. Tingkat kesulitan, panjangnya bahan ajar, bahkan berartinya sebuah bahan ajar bagi siswa dapat mempengaruhi aktivitas belajar siswa tersebut. $b$. Berat-ringannya tugas. Tugas yang terlalu ringan atau mudah dapat mengurangi tantangan belajar, sedangkan 
tugas yang terlalu berat atau sukar dapat membuat seorang siswa jera. Sehingga, hal ini akan berpengaruh pada aktivitas belajar siswa. c. Suasana lingkungan eksternal. Suasana lingkungan eksternal yang menyangkut banyak hal seperti: cuaca, waktu, kondisi tempat, penerangan. Faktor-faktor ini berpengaruh pada reaksi siswa dalam aktivitas belajarnya. d. Metode belajar. Metode mengajar yang dipakai oleh guru sangat mempengaruhi metode belajar yang dipakai siswa. Dengan kata lain, metode yang dipakai oleh guru menimbulkan perbedaan yang berarti bagi aktivitas belajar siswa.

Belajar aktif menuntut guru bekerja secara profesional, mengajar secara sistematis, dan berdasarkan prinsip-prinsip pembelajaran yang efektif dan efisien. Salah satu teknik yang akan dipergunakan untuk meningkatkan active learning anak usia dini di dalam kelas adalah token economy. Token economy adalah penerapan operant conditioning dengan mengganti hadiah langsung dengan sesuatu yang dapat ditukarkan kemudian (Palmer S, 2011). Disebut operant karena memberikan perlakuan terhadap lingkungan yaitu hadiah kepada tingkah laku yang diharapkan. Token Economy (tabungan kepingan) menurut (Runukahu, 2013) adalah sebuah sistem yang merupakan kombinasi berbagai prosedur perilaku efektif terutama prosedur pengukuhan kontigensi perilaku yang potensial. Secara teknis Token Economy merupakan teknik pengukuran perilaku untuk seorang siswa dengan cara memberikan hadiah secara simbolik. Oleh karena itu penggunaan teknik token economy diharapkan dapat menciptakan kesenangan, ketertarikan dan kesukarelaan anak untuk aktif dalam proses belajar di dalam kelas.

Penerapan pemberian reward dengan cara memberikan stiker bintang sepertinya masih belum efektif dalam meningkatkan active learning pada anak usia dini. Hal ini dikarenakan anak merasa cepat puas dengan perolehan bintangnya dan guru juga kesulitan mempertahankan keaktifan belajar siswa walaupun telah menggunakan stiker bintang sebagai reinforce positive. Oleh karena itu dalam penelitian ini, peneliti akan menggunakan hadiah sebagai penguatan ekstrinsik dalam peningkatan active learning anak usia dini.

Anak akan mengumpulkan koin reward setiap harinya yang. Token akan dikumpulkan dan dapat dipertukarkan dengan suatu obyek atau kehormatan yang penuh arti (Davidson, 2010). Anak dapat memilih hadiah mana yang mereka inginkan sesuai dengan nilai yang didapatkan dari koin tersebut. Guru akan memfasilitasi dalam proses penukaran hadiah token tersebut. Dalam hal ini hadiah merupakan penguat ekstrinsik untuk meningkatkan active learning anak.

Berdasarkan informasi wawancara yang diperoleh di TK Sinar Cahaya Bangsa Denpasar diketahui bahwa pembelajaran aktif dalam proses pembelajaran sehari-hari belum optimal dalam pengaplikasiannya. Hal ini disebabkan keterbatasan waktu belajar karena 1 kelas digunakan untuk 2 kelompok belajar (kelas pagi dan siang), sehingga waktu dirasa kurang dalam pengaplikasiannya. Sedangkan penggunaan token economy sebagai penguat ekstrinsik juga belum diaplikasikan secara optimal dalam proses pembelajaran. Hal ini dikarenakan Oleh karena itu penerapan Token Economy ini diharapkan dapat meningkatkan active learning anak usia dini sehingga menjadi referensi bagi guru dalam meningkatkan active learning d ikelas. Berdasarkan penelitian kami sebelumnya (Prima, E \& Lestari, 2018) ditemukan bahwa penerapan token economy dapat meningkatkan kedisiplinan pada anak usia dini. Sehingga kami menduga melalui penerapan teknik token economy, juga akan meningkatkan active learning anak usia dini.

\section{METODOLOGI}

Penelitian ini merupakan penelitian Quasi Experimental Design, rancangan yang digunakan adalah non equivalent control group design. Pada penelitian ini penentuan kelompok kontrol dan kelompok eksperimen dilakukan secara acak. Dalam rancangan ini subjek diambil dari populasi yaitu 20 anak kelas eksperimen dan 20 anak di kelas kontrol (Sugiyono, 2017). Rancangan eksperimen quasi digunakan jika variabel-variabel luar yang mempengaruhi 
eksperimen tidak sepenuhnya bisa dikontrol serta pemilihan subjek penelitian ini tidak dapat dilakukan dengan pengacakan individu.

Rancangan penelitian non equivalent control group design seperti pada Gambar 1.

$$
\frac{01 \quad \times 02}{03 \quad 04}
$$

Gambar 1. Rancangan penelitian non equivalent control group design

(Sumber: Sugiyono, 2017)

Keterangan :

$\mathrm{O} 1=$ pretest $\mathrm{kelompok}$ eksperimen

$\mathrm{O} 2=$ posttest kelompok eksperimen

$\mathrm{X}=$ perlakuan dengan menggunakan token economy

$\mathrm{O} 3=$ pretest $\mathrm{kelompok}$ kontrol

$\mathrm{O} 4=$ posttest kelompok kontrol

Terdapat dua kelompok dalam rancangan ini yaitu kelompok eksperimen dan kelompok kontrol, satu mendapatkan perlakuan dan satu kelompok kontrol, keduanya memperoleh pre-test dan post-test. Dalam penelitian ini diberikan perlakukan post-test untuk mengetahui perkembangan anak. Pemberian pre-test biasanya digunakan untuk mengukur equivalensi atau penyetaraan kelompok (Dantes, 2017).

Langkah-langkah yang ditempuh dalam penelitian ini terdiri tiga tahapan yang dapat dijelaskan dengan tabel 1.

Tabel 1. Langkah-langkah penelitian

\begin{tabular}{|c|c|c|c|}
\hline No & Persiapan eksperimen & Pelaksanaan eksperimen & Akhir eksperimen \\
\hline 1 & Melaksanakan observasi; & melakukan pre-test; & $\begin{array}{l}\text { hasil observasi pada pre-test } \\
\text { dan post-test tentang } \\
\text { peningkatan active learning; }\end{array}$ \\
\hline 2 & $\begin{array}{l}\text { Menentukan } \\
\text { eksperimen; }\end{array}$ & $\begin{array}{l}\text { memberikan pengarahan } \\
\text { terhadap guru kelas mengenai } \\
\text { teknik token economy; }\end{array}$ & $\begin{array}{l}\text { Analisis hasil penelitian } \\
\text { untuk menguji hipotesis } \\
\text { yang diajukan diterima atau } \\
\text { ditolak; }\end{array}$ \\
\hline 3 & $\begin{array}{l}\text { Menyusun } \mathrm{RPPH} \text { dan } \\
\text { sumber belajar; dan }\end{array}$ & $\begin{array}{l}\text { melaksanakan penelitian yaitu } \\
\text { memberikan perlakuan pada } \\
\text { kelas eksperimen dengan } \\
\text { penerapan teknik token } \\
\text { economy; dan }\end{array}$ & $\begin{array}{l}\text { menyusun pembahasan } \\
\text { mengenai hasil analisis; dan }\end{array}$ \\
\hline 4 & Menyusun rubrik penilaian & $\begin{array}{l}\text { memberikan post-test terhadap } \\
\text { peningkatan active learning } \\
\text { pada kelas eksperimen. }\end{array}$ & kesimpulan hasil penelitian. \\
\hline
\end{tabular}

Variabel yang digunakan dalam penelitian ini adalah variabel Bebas (Variabel Independen) adalah penerapan teknik token economy dan variabel terikat (Variabel Dependen) adalah peningkatan active learning anak.

Adapun jenis data yang digunakan dalam penelitian ini adalah data kuantitatif berupa jumlah siswa dan hasil observasi. Sedangkan sumber data dalam penelitian ini, adalah: a) Sumber data primer yaitu wawancara kepala sekolah dan guru TK Sinar Cahaya Bangsa, instrumen dan dokumentasi dan b) Sumber data sekunder adalah data yang langsung dikumpulkan oleh peneliti seperti kajian pustaka. 


\section{HASIL DAN PEMBAHASAN}

\section{Hasil Pengumpulan Data}

Data yang dianalisis pada penelitian ini adalah peningkatan active learning pada anak Kelompok B TK Sinar Cahaya Bangsa Denpasar. Data peningkatan active learning anak diperoleh dari hasil post-test yang diberikan pada akhir penelitian. Kelompok eksperimen yang digunakan dalam penelitian ini yaitu Kelompok B1 yang berjumlah 20 anak sedangkan kelompok kontrol adalah Kelompok B2 berjumlah 20 anak. Maka jumlah siswa dalam penelitian ini sebanyak 40 anak. Instrumen yang digunakan untuk mengumpulkan data adalah rubrik penilaian. Rancangan penelitian yang digunakan dalam penelitian ini adalah nonequivalent control group design dengan mengujikan uji-t sebagai alat ukur menganalisis data.

Kelompok B1 sebagai kelas eksperimen dan Kelompok B2 sebagai kelas kontrol diberikan pretest di awal penelitian. Kelompok B1 sebagai kelompok eksperimen yang diberikan perlakuan berupa penerapan token economy kemudian diberikan post-test untuk memperoleh peningkatan active learning anak. Begitu pula Kelompok B2 sebagai kelompok kontrol diberi perlakuan berupa pelajaran konvensional, kemudian diberikan post-test untuk memperoleh peningkatan active learning anak.

\section{Uji Instrument}

Sebelum melakukan penelitian, instrument yang sudah dibuat dilakukan pengujian melibatkan 20 orang siswa. Hal ini bertujuan untuk memberikan hasil ukur yang tepat dan akurat sehingga menghasilkan data yang relevan. Uji instrument ada 2 macam yaitu uji validitas dan realibitas.

\section{Uji Validitas}

Butir indikator yang digunakan dalam penelitian ini diuji validitasnya dengan hasil seperti pada Tabel 2.

Tabel 2. Validitas Indikator Correlations

\begin{tabular}{|c|c|c|c|c|c|c|c|}
\hline & & 1 & 2 & 3 & 4 & 5 & SUM \\
\hline \multirow[t]{3}{*}{1} & Pearson Correlation & 1 & $.798^{* *}$ & .356 & $.892^{* *}$ & $.711^{* *}$ & $.958^{* \star}$ \\
\hline & Sig. (2-tailed) & & .000 & .123 & .000 & .000 & .000 \\
\hline & $\mathrm{N}$ & 20 & 20 & 20 & 20 & 20 & 20 \\
\hline \multirow[t]{3}{*}{2} & Pearson Correlation & $.798^{* *}$ & 1 & .363 & $.632^{* *}$ & $.499^{*}$ & $.819^{* *}$ \\
\hline & Sig. (2-tailed) & .000 & & .116 & .003 & .025 & .000 \\
\hline & $\mathrm{N}$ & 20 & 20 & 20 & 20 & 20 & 20 \\
\hline \multirow[t]{3}{*}{3} & Pearson Correlation & .356 & .363 & 1 & .275 & .413 & .540 \\
\hline & Sig. (2-tailed) & 123 & .116 & & .241 & .070 & .042 \\
\hline & $\mathrm{N}$ & 20 & 20 & 20 & 20 & 20 & 20 \\
\hline \multirow[t]{3}{*}{4} & Pearson Correlation & $.892^{* *}$ & $.632^{* *}$ & .275 & 1 & $.819^{* *}$ & $.937^{* *}$ \\
\hline & Sig. (2-tailed) & .000 & .003 & .241 & & .000 & .000 \\
\hline & $\mathrm{N}$ & 20 & 20 & 20 & 20 & 20 & 20 \\
\hline \multirow[t]{3}{*}{5} & Pearson Correlation & $.711^{* *}$ & $.499^{*}$ & .413 & $.819^{* *}$ & 1 & $.845^{* \star}$ \\
\hline & Sig. (2-tailed) & .000 & .025 & .070 & .000 & & .000 \\
\hline & $\mathrm{N}$ & 20 & 20 & 20 & 20 & 20 & 20 \\
\hline $\mathrm{S}$ & Pearson Correlation & $.958^{* *}$ & $.819^{* *}$ & .540 & $.937^{* *}$ & $.845^{* *}$ & 1 \\
\hline & Sig. (2-tailed) & .000 & .000 & .042 & .000 & .000 & \\
\hline M & $\mathrm{N}$ & 20 & 20 & 20 & 20 & 20 & 20 \\
\hline \multicolumn{8}{|c|}{$\begin{array}{l}\text { **. Correlation is significant at the } 0.01 \text { level (2-tailed). } \\
\text { *. Correlation is significant at the } 0.05 \text { level (2-tailed). }\end{array}$} \\
\hline
\end{tabular}

Dari tabel 2 diperoleh hasil Indikator $1=0,958$; Indikator $2=0,819$; Indikator $3=0,540$; Indikator $4=0,937$; dan Indikator $5=0,845$. Hasil hitung setiap indikator di atas $0,05(>0,05)$ hal ini menunjukkan indikator sebagai alat ukur adalah valid. 


\section{Uji Reabilitas}

Indikator yang digunakan dalam penelitian ini kemudian dihitung pula reabilitas butir indikator. Hasil pengukuran Uji Reabilitas seperti pada Tabel 3 dan Tabel 4. Nilai rata-rata per indkator antara 3,25 sampai 3,95. Kemudian dihitung reabilitas butir indikator mendapatkan hasil $\mathrm{R}$ hitung $=0,872$ dengan $\mathrm{dk}=38$ diperoleh nilai $\mathrm{R}_{\text {tabel }}=0,2638$ sehingga $\mathrm{R}_{\text {hitung }}=0,872>$ $R_{\text {tabel }}=0,2638$. Hasil menunjukkan indikator yang digunakan sebagai alat ukur adalah valid.

Tabel 3. Item Statistics Nilai Per Indikator

\begin{tabular}{cccc}
\hline Indikator & Mean & Std. Deviation & $\mathrm{N}$ \\
\hline 1 & 3.6500 & 1.08942 & 20 \\
2 & 3.3500 & .87509 & 20 \\
3 & 3.9500 & .22361 & 20 \\
4 & 3.2500 & 1.06992 & 20 \\
5 & 3.4500 & .82558 & 20 \\
\hline
\end{tabular}

Tabel 4. Reliability Statistics

\begin{tabular}{cc}
\hline $\begin{array}{c}\text { Cronbach's } \\
\text { Alpha }\end{array}$ & N of Items \\
\hline .872 & 5 \\
\hline
\end{tabular}

\section{Deskripsi Data Kompetensi Peningkatan Active Learning}

Deskripsi data kompetensi peningkatan active learning menggunakan bantuan analisis SPSS 17 For Windows. Deskripsi data pada Tabel 4.

Tabel 4. Deskripsi Data Kompetensi Peningkatan Active Learning Statistics

\begin{tabular}{lrrrr}
\hline & Pre test eks & Post eks & Pre kontrol & Post kontrol \\
\hline $\mathrm{N} \quad$ Valid & 20 & 20 & 20 & 20 \\
\multicolumn{1}{c}{ Missing } & 0 & 0 & 0 & 0 \\
Mean & 2.5000 & 3.4000 & 2.3500 & 2.3000 \\
Std. Error of & .17014 & .15218 & .18173 & .16384 \\
Mean & & & & \\
Median & 3.0000 & 3.5000 & 2.0000 & 2.0000 \\
Mode & 3.00 & 4.00 & $2.00 \mathrm{a}$ & 3.00 \\
Std. Deviation & .76089 & .68056 & .81273 & .73270 \\
Variance & .579 & .463 & .661 & .537 \\
Minimum & 1.00 & 2.00 & 1.00 & 1.00 \\
Maximum & 4.00 & 4.00 & 4.00 & 3.00 \\
Sum & 50.00 & 68.00 & 47.00 & 46.00 \\
\hline
\end{tabular}

a. Multiple modes exist. The smallest value is shown

Dari tabel 5 menggunakan bantuan SPSS 17 For Windows, didapat: rata-rata (mean) pada saat pretest kelas eksperimen sebesar 2,50 dan pada saat post-test sebesar 3,40 terjadi peningkatan dari pretest ke post-test sebesar 0,9 (36\%). Nilai tengah (median) pada saat pretest sebesar 3,00 dan pada saat post-test sebesar 3,50. Nilai yang sering muncul (mode/modus) pada saat pretest sebesar 3,00 dan pada saat post-test sebesar 4,00. Standar Deviasi pada saat pretest sebesar 0,76 dan pada saat post-test sebesar 0,68 terjadi penurunan karena standar deviasi 
merupakan cerminan dari rata-rata penyimpangan data dari mean, standar deviasi juga dapat menggambarkan seberapa jauh bervariasinya data. Varians pada saat pretest sebesar 0,579 dan pada saat post-test sebesar 0,463, terjadi penurunan karena varians menunjukkan ukuran variabilitas (kecenderungan berubah-ubah) dan persebaran nilai hasil observasi terhadap ratarata.

Sementara itu pretest kelas kontrol memiliki rata-rata (mean) sebesar 2,35 dan pada saat post-test sebesar 2,30, terjadi penurunan dari pretest ke post-test sebesar 0,5 (21,28\%). Nilai tengah (median) pada saat pretest sebesar 2,00 dan pada saat post-test sebesar 2,00. Nilai yang sering muncul (mode/modus) pada saat pretest sebesar 2,00 dan pada saat post-test sebesar 3,00. Standar Deviasi pada saat pretest sebesar 0,81 dan pada saat post-test sebesar 0,73 terjadinya penurunan karena standar deviasi merupakan cerminan dari rata-rata penyimpangan data dari mean, standar deviasi juga dapat menggambarkan seberapa jauh bervariasinya data. Varians pada saat pretest sebesar 0,661 dan pada saat post-test sebesar 0,537, terjadinya penurunan karena varians menunjukkan ukuran variabilitas (kecenderungan berubah-ubah) dan persebaran nilai hasil observasi terhadap rata-rata.

Sebelum dilakukan pengujian hipotesis dengan analisis uji-t, terlebih dahulu harus dilakukan uji prasyarat yang meliputi uji normalitas sebaran data dan uji homogenitas varians.

Untuk mengetahui sebaran data peningkatan active learning anak berdistribusi normal dan tidak, maka data di uji menggunakan analisis SPSS 17 For Windows. Rekapitulasi hasil uji normalitas data kelompok eksperimen dan kelompok kontrol pada Tabel 5 adalah sebagai berikut:

Tabel 5. Rekapitulasi Hasil Uji Normalitas Data Kelompok Eksperimen dan Kelompok Kontrol

Tests of Normality

\begin{tabular}{lrrrrrr}
\hline & \multicolumn{3}{c}{ Kolmogorov-Smirnov $^{\mathrm{a}}$} & \multicolumn{3}{c}{ Shapiro-Wilk } \\
\hline & Statistic & df & \multicolumn{1}{l}{ Sig. } & \multicolumn{1}{c}{ Statistic } & df & \multicolumn{1}{l}{ Sig. } \\
\hline Pre eks & .134 & 20 & $.200^{*}$ & .960 & 20 & .547 \\
Post eks & .130 & 20 & $.200^{*}$ & .953 & 20 & .411 \\
Pre kontrol & .110 & 20 & $.200^{*}$ & .967 & 20 & .691 \\
Post & .096 & 20 & $.200^{*}$ & .978 & 20 & .912 \\
kontrol & & & & & & \\
\hline
\end{tabular}

a. Lilliefors Significance Correction

*. This is a lower bound of the true significance.

Berdasarkan uji normalitas sebaran data kelompok kontrol menggunakan SPSS 17 For Windows, menggunakan Kolmogorov-Smirnov untuk data kelas eksperimen hasil pretest sig 0,134 dan untuk data post-test 0,130. Sedangkan kelas kontrol hasil pretest sig 0,110 dan untuk data post-test 0,096. Hasil menunjukkan data terdistribusi normal karena keseluruhan nilai sig $>0,05$ sehingga disimpulkan bahwa sebaran data untuk pretest dan post-test berdistribusi normal.

Uji homogenitas varians dilakukan terhadap data peningkatan active learning kelompok eksperimen dan kelompok kontrol. Dari hasil perhitungan $\mathrm{F}=1,14$ sedangkan Ftabel pada taraf signifikansi $5 \%$ dengan derajat kebebasan (dk pembilang 20-1=19 dan dk penyebut 20-1=19) = 2,74, sehingga Fhitung $=1,14<$ Ftabel $=2,74$ maka varians kedua kelompok data homogen. Ini berarti bahwa varian antara kelompok anak yang diajarkan melalui penerapan token economy dan kelompok anak yang dibelajarkan melalui pembelajaran konvensional homogen. 
Hipotesis penelitian yang diuji adalah Ho yang berbunyi tidak terdapat perbedaan yang signifikan peningkatan active learning anak yang dibelajarkan melalui penerapan teknik token economy dengan anak yang dibelajarkan melalui pembelajaran konvensional pada anak kelompok B. Berdasarkan hasil uji normalitas dan uji homogenitas varians yang diperoleh kedua kelompok (eksperimen dan kontrol) berdistribusi normal dan varians kedua kelompok homogen, berdasarkan hal tersebut maka statistik yang digunakan dalam penelitian ini adalah uji-t dengan rumus polled varians. Dengan kriteria pengujian jika thitung < ttabel, maka Ho diterima, dan jika harga thitung $>$ ttabel, maka Ho ditolak, pada taraf signifikansi $5 \%(a=0,05)$ dengan derajat kebebasan $(\mathrm{dk}=20+20-2=38)$ diperoleh nilai ttabel $=1,682$. Hasil perhitungan uji hipotesis perhitungan disajikan dalam Tabel 6 berikut:

Tabel 6. Tabel Uji Hipotesis Kelompok Eksperimen dan Kelompok Kontrol Paired Samples Test

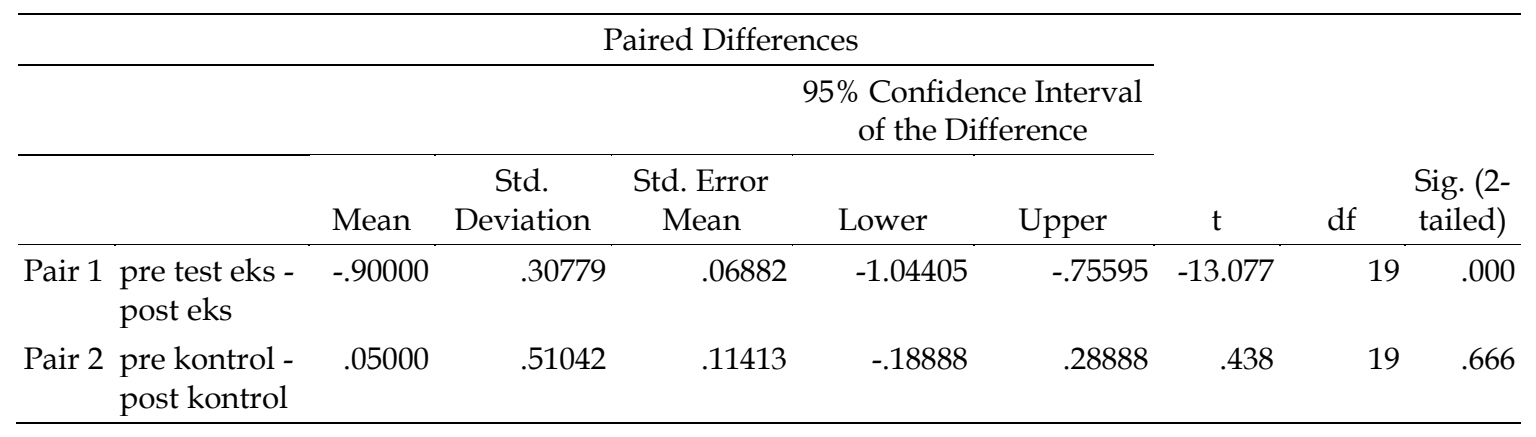

Berdasarkan tabel 6, untuk kelas eskperimen diperoleh thitung $=13,077$ sedangkan pada taraf signifikansi $5 \%$ dengan $\mathrm{dk}=38$ diperoleh nilai ttabel $=2,538$ sehingga thitung $=$ 13,077 > ttabel $=2,358$. Dapat dilihat bahwa thitung $>$ ttabel yaitu 13,077 > 2,358. Hasil menunjukkan perlakuan eksperimen memberikan pengaruh yang signifikan atau berbeda nyata (H1 diterima Ho ditolak) $\mathrm{p}$ value $<0.05(0.00<0.05)$. Sementara untuk kelas kontrol diperoleh thitung $=0,438$ sedangkan pada taraf signifikansi $5 \%$ dengan $\mathrm{dk}=38$ diperoleh nilai ttabel $=2,538$ sehingga thitung $=0,438<$ ttabel $=2,358$. Dapat dilihat bahwa thitung $<$ ttabel yaitu $0,438<2,358$. Hasil menunjukkan perlakuan kontrol tidak memberikan pengaruh yang signifikan atau berbeda tidak nyata (H1 ditolak Ho diterima) $p$ value $>0.05(0.666>0,05)$.

Dengan hasil tersebut maka dapat disimpulkan bahwa H0 menyatakan tidak terdapat perbedaan yang signifikan peningkatan active learning anak antara kelompok eksperimen dan kelompok kontrol anak Kelompok B di TK Sinar Cahaya Bangsa Tahun Ajaran 2020/2021 ditolak, dan $\mathrm{H} 1$ yang menyatakan bahwa terdapat perbedaan yang signifikan peningkatan active learning anak antara kelompok kontrol dan kelompok eksperimen anak Kelompok B diterima. Sehingga dapat dikatakan bahwa terdapat perbedaan yang signifikan antara peningkatan active learning anak yang dibelajarkan dengan penerapan teknik token economy dengan anak yang tidak dibelajarkan melalui penerapan teknik token economy pada anak Kelompok B TK Sinar Cahaya Bangsa Tahun Ajaran 2020/2021.

\section{Pembahasan}

Berdasarkan hasil analisis data pretest dan post-test dari kedua kelompok penelitian diperoleh nilai rata-rata hasil pretest kelompok eksperimen adalah 2,50 dan nilai rata-rata posttest adalah 3,40. Sedangkan nilai rata-rata hasil pretest kelompok kontrol adalah 2,35 dan nilai rata-rata post-test adalah 2,30. Dilihat dari nilai rata-rata post-test kedua kelompok tersebut, maka dapat dikatakan kelompok yang dibelajarkan melalui penerapan teknik token economy memiliki nilai rata-rata lebih besar dibandingkan yang dibelajarkan melalui pembelajaran konvensional. 
Setelah mendapatkan hasil post-test, maka dilakukan uji prasyarat terlebih dahulu sebelum dilanjutkan ke uji-t. Adapun uji prasyarat yang dilakukan adalah uji normalitas dan uji homogenitas yang menunjukkan bahwa sebaran data post-test kedua kelompok tersebut berdistribusi normal dan varians data kedua kelompok tersebut homogen. Setelah data dinyatakan berdistribusi normal dan varians data homogen, maka analisis data dilanjutkan dengan menggunakan uji-t.

Dari hasil uji-t diperoleh thitung $=13,077$ dan taraf signifikan $5 \%$ dengan derajat kebebasan 38 diperoleh $t_{\text {tabel }}=2,538$. Dengan membandingkan hasil $t_{\text {hitung }}$ dan $t_{\text {tabel }}$ dapat disimpulkan bahwa $t_{\text {hitung }}>t_{\text {tabel }}(13,077>2,538)$, maka $\mathrm{H}_{1}$ diterima dan $\mathrm{H}_{\mathrm{o}}$ ditolak. Berdasarkan hasil perhitungan uji-t menunjukkan bahwa terdapat perbedaan yang signifikan antara kelompok yang dibelajarkan dengan penerapan teknik token economy dengan anak yang dibelajarkan dengan pembelajaran konvensional pada anak Kelompok B TK Sinar Cahaya Bangsa.

Hal ini disebabkan karena didalam penerapan teknik token economy anak-anak distimulasi dengan pemberian reward sebagai penguat eksternal. Penguatan (reinforcement) menurut Usman dalam Calista et al. (2019) adalah segala bentuk respon, apakah bersifat verbal maupun nonverbal, yang merupakan bagian dari modifikasi tingkah laku guru terhadap tingkah laku anak, yang bertujuan untuk memberikan informasi atau umpan balik (feedback) bagi si penerima (anak) atas perbuatannya sebagai suatu tindak dorongan ataupun koreksi. Tujuan pemberian reinforcement menurut Marno dalam (Masruroh \& Dewi, 2020) yaitu: a) Meningkatkam perhatian, b) Membangkitkan dan memelihara dan meningkatkan motivasi, c) Mengarah pada pengembangan berfikir ke arah devergen, d) Mengatur dan mengarahkan ke proses belajar, dan e) Mengendalikan serta memokasi tingkah laku yang kurang positif ke arah tingkah laku yang produktif. Reward itu sendiri dapat dibedakan menjadi dua, yaitu reward verbal dan reward non-verbal (Mulyadi dalam (Madiyanah \& Farihah, 2020). Dalam hal ini peneliti menggunakan reward non-verbal sebagai penguatan.

Teknik token economy dirancang untuk meningkatkan perilaku yang diinginkan dan mengurangi perilaku yang tidak diinginkan dengan penggunaan token. Setelah beberapa token terkumpul, maka dapat ditukar dengan hadiah (reinfocer) sesuai dengan jumlah token yang diperolehnya (Lessing, 2015). Anak akan diberikan token saat menunjukkan pembelajaran aktif, misalnya saat anak mau menjawab pertanyaan guru selama proses belajar berlangsung maka koin token akan diberikan kepada anak dengan cara guru memasukkan ke dalam celengan anak sesuai dengan kriteria penilaian yang ada. Setelah 3 kali pertemuan maka koin akan dijumlahkan dan dapat ditukarkan dengan hadiah sesuai dengan nilai koin yang didapatkan. Hadiah akan didapatkan segera setelah koin terkumpul selama 3 kali pertemuan. Dalam dunia pendidikan, hadiah dapat dijadikan sebagai alat motivasi dalam membentuk perilaku anak (Arifatun dalam (Ramadhani \& Aulia, 2020).

Berbeda pada kelompok kontrol, kegiatan pembelajaran tidak dilakukan dengan pemberian reward. Reward sebagai alat pendidikan diberikan ketika seorang anak melakukan sesuatu yang baik, atau telah berhasil mencapai sebuah tahap perkembangan tertentu, atau tercapainya sebuah target (Sabartiningsih et al., 2018). Sehingga pada kelompok kontrol proses pembelajaran terlihat kurang aktif dan optimal. Padahal salah satu dari prinsip pembelajaran adalah menarik perhatian (gaining attention) yaitu hal yang menimbulkan minat siswa dengan mengemukakan sesuatu yang baru, aneh, kontradiksi atau kompleks (Suciati, 2001). Dalam hal ini reward melalui token economy merupakan sesuatu yang baru dan menarik perhatian yang diharapkan akan menimbulkan minat siswa dalam meningkatkan pembelajaran active learning saat pembelajaran berlangsung. Reinschluessel dan Mandryk, dalam (Amalo \& Widiastuti, 2020) mengatakan bahwa positive reinforcement memiliki pengaruh yang lebih efektif dari pada negative reinforcement. Namun hal ini tidak ditemukan pada kelas kontrol karena tidak ada penerapan token economy dalam proses pembelajaran.

Ormrod (2008) menyatakan bahwa token economy efektif untuk diterapkan pada seluruh tingkat usia. Pada situasi dimana kontrol yang sangat ketat dibutuhkan maka teknik 
token economy menjadi metode intervensi yang baik. Dalam token economy tingkah laku yang diharapkan muncul bisa diperkuat dengan sesuatu yang diinginkan oleh anak, sehingga hasil perilaku yang diharapkan oleh pendidik dapat ditukar dengan sesuatu yang diinginkan oleh anak.

Senada dengan hal ini, penelitian yang telah dilakukan (Prima, E \& Lestari, 2020) dengan jenis penelitian tindakan kelas yang berjudul, "Penerapan Teknik Token Economy Untuk Meningkatkan Perilaku Prososial Anak Usia Dini" menunjukkan bahwa terjadi peningkatan perilaku prososial dengan penerapan teknik Token Economy. Pada Siklus I perilaku prososial sebesar $54,94 \%$ yang berada pada kategori rendah mengalami peningkatan pada Siklus II menjadi 82,35 \% yang tergolong pada kategori tinggi.

Berdasarkan paparan tersebut dapat dikatakan bahwa Penerapan Teknik Token Economy berpengaruh terhadap Peningkatan Active Learning Anak Kelompok B di TK Sinar Cahaya Bangsa Tahun Ajaran 2020/2021.

\section{SIMPULAN}

Terdapat peningkatan active learning saat proses pembelajaran dengan penerapan token economy. Jenis token yang dipergunakan dalam penelitian ini adalah koin yang ditabungkan dalam celengan masing-masing anak. Anak terlihat antusias berpartisipasi saat proses pembelajaran berlangsung, sehingga menampilkan peningkatan active learning saat proses pembelajaran. Berdasarkan uraian diatas dapat disimpulkan bahwa terdapat peningkatan active learning dengan penerapan teknik token economy dalam penelitian ini..

\section{UCAPAN TERIMA KASIH}

Penulis mengucapkan terima kasih kepada pihak yang telah berperan pada penelitian ini. Penulis mengucapkan terima kasih kepada DPRM Kemenristek-BRIN, Rektor Universitas Dhyana Pura, Dekan Fakultas Ekonomika dan Humaniora Universitas Dhyana Pura serta Ketua dan staf LPPM yang telah memfasilitasi penelitian ini. Ketua Program Studi PG-PAUD Universitas Dhyana Pura, Kepala Sekolah TK Sinar Cahaya Bangsa yang telah memberikan kesempatan untuk dapat meneliti, serta semua pihak yang telah membantu terselesaikannya penelitian ini.

\section{DAFTAR PUSTAKA}

Amalo, I. G., \& Widiastuti, A. A. (2020). Pengaruh Penggunaan Token Ekonomi dalam Menurunkan Perilaku Disruptif Anak. Jurnal Obsesi : Jurnal Pendidikan Anak Usia Dini, 5(1), 500. https://doi.org/10.31004/obsesi.v5i1.622

Calista, V., Kurniah, N., \& Ardina, M. (2019). Hubungan Reinforcement Terhadap Disiplin Anak Usia Dini Di Paud Pembina 1 Kota Bengkulu (Studi Deskriptif Kuantitatif Di PAUD Pembina 1 Kota Bengkulu). Jurnal Ilmiah POTENSIA, 4(1), 13-17. https://doi.org/10.33369/jip.4.1.13-17

Dantes, N. (2017). Desain Eksperimen dan Analisis Data. PT Raja Grafindo Persada.

Davidson, G. (2010). Psikologi Abnormal. Rajawali Press.

Dimyati, \& Mudjiono. (2013). Belajar dan Pembelajaran. PT Rineka Cipta.

Hamruni. (2012). Strategi Pembelajaran. Insan Madani.

Hasanah, U. (2019). Strategi Pembelajaran Aktif untuk Anak Usia Dini. INSANIA : Jurnal Pemikiran Alternatif Kependidikan, 23(2), 204-222. https://doi.org/10.24090/insania.v23i2.2291

Lessing, A. \& R. W. (2015). The potential of behaviour management strategies to support learners with attention deficit hyperactivity disorder in the classroom. Journal Education as Change. Education as Change, 19(1), 55-77.

Madiyanah \& Farihah. (2020). Meningkatkan Disiplin Anak Usia Dini Melalui Pemberian Reward,. Jurnal Teladan, 5(1), 17-26. 
Masruroh, S., \& Dewi, N. F. K. (2020). Penerapan Reinforcement Dalam Mendisiplinkan Anak Usia 5-6 Tahun di TK Islam Kinasih Kecamatan Pinang Tangerang. Ceria, 11(2), 55-66. https:// doi.org/http://dx.doi.org/10.31000/ceria.v11i2

Ormrod, J. E. (2008). Psikologi Pendidikan: Membantu Siswa Tumbuh dan Berkembang edisi Keenam. Erlangga.

Palmer S. (2011). Konseling dan Psikoterapi. Pustaka Pelajar.

Panjaitan, N. Q., Yetti, E., \& Nurani, Y. (2020). Pengaruh Media Pembelajaran Digital Animasi dan Kepercayaan Diri terhadap Hasil Belajar Pendidikan Agama Islam Anak. Jurnal Obsesi: Jurnal Pendidikan Anak Usia Dini, 4(2), 588. https:// doi.org/10.31004/obsesi.v4i2.404

Prima, E \& Lestari, P. I. (2018). Penerapan Teknik Token Economy Untuk Meningkatkan Kedisiplinan Anak Usia Dini. Obsesi, 2(2), 247-254. https:// doi.org/10.31004/obsesi.v2i2.124

Prima, E \& Lestari, P. I. (2020). Penerapan Token Economy untuk Meningkatkan Perilaku $\begin{array}{llll}\text { Prososial Anak Usia Dini. Obsesi, 4(1), 258-266. } & \end{array}$ https:// doi.org/https:// doi.org/10.31004/obsesi.v4i1

Ramadhani, J. S., \& Aulia, P. (2020). Keunggulan Token Economy untuk Meningkatkan Perilaku Antri pada Anak Usia Dini. Jurnal Pendidikan Tambusai, 4(2), 1111-1119. https:// doi.org/https:// doi.org/10.31004/jptam.v4i2.574

Runtukahu, T. (2013). Analisis Perilaku Terapan Untuk Guru. Ar-Ruzz Media.

Sabartiningsih, M., Muzakki, J. A., \& Durtam, D. (2018). Implementasi Pemberian Reward dan Punishment dalam Membentuk Karakter Disiplin Anak Usia Dini. AWLADY : Jurnal Pendidikan Anak, 4(1), 60. https:/ / doi.org/10.24235/awlady.v4i1.2468

Soemanto, W. (2012). Psikologi Pendidikan Landasan Kerja Pemimpin Pendidikan. Rineka Cipta. Solihatin. (2011). Pengajaran Active Learning dengan Model Pengajaran Terarah. PT Rineka Cipta. Suciati, P. I. (2001). Teori Belajar dan Motivasi. PAU-PPAI Universitas Terbuka.

Sugiyono. (2017). Metode Penelitian Pendidikan: Pendekatan Kuantitatif, Kualitatif, R\&D. Cetakan Ke-25. Bandung: CV Alfabeta.

Wina, S. (2016). Strategi Pembelajaran: Berorientasi Standart Proses Pendidikan (12th ed.). Prenada Media.

Zamzami, E. M. (2021). Aplikasi Edutainment Pendukung Pembelajaran Jarak Jauh TK Merujuk Standar Nasional PAUD. Jurnal Obsesi : Jurnal Pendidikan Anak Usia Dini, 5(2), 985-995. https://doi.org/10.31004/obsesi.v5i2.750 